\title{
Assessment of heavy metals concentration in groundwater and their associated health risks near an industrial area
}

\author{
Bahareh Lorestani $^{1(}$, Hajar Merrikhpour $^{2^{*}}{ }^{\left(M^{\circ}\right.}$ Mehrdad Cheraghi $^{1}{ }^{(0}$ \\ ${ }^{1}$ Department of Environmental Science, College of Basic Sciences, Hamedan Branch, Islamic Azad University, Hamedan, Iran \\ ${ }^{2}$ Department of Agriculture, Sayyed Jamaleddin Asadabadi University, Asadabad, Iran
}

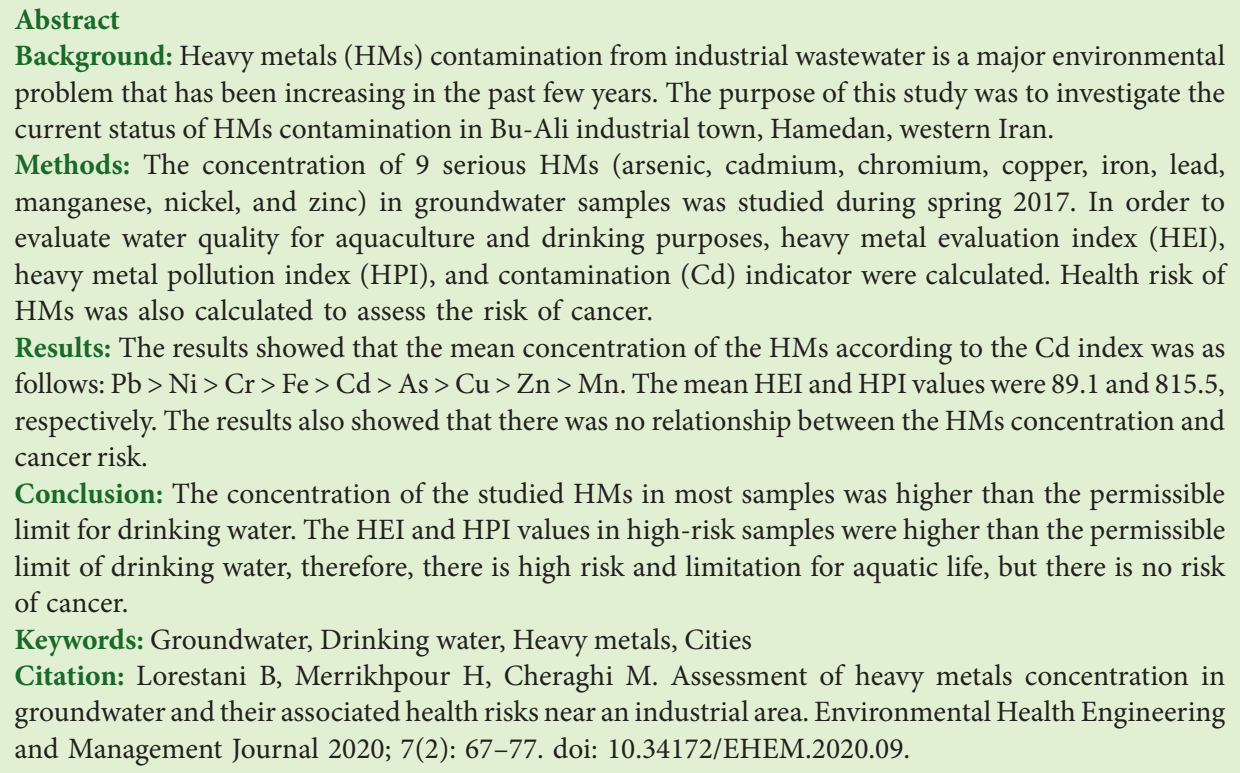

Article History:

Received: 4 December 2019

Accepted: 30 May 2020

ePublished: 18 June 2020

\section{Introduction}

Today, with limited water resources, less than one percent of available water resources are suitable for human consumption (1). Therefore, it is essential to protect water resources with proper management. Groundwater conservation, especially in arid and semi-arid regions, has particular economic importance. The rapid growth of population and urbanization over the past decades had a major impact on groundwater quality due to overutilization and increased agricultural demand, domestic and industrial water supply. Excessive use of groundwater as a result of population growth has led to a reduction in these valuable resources (2). Given the growth of industries, more concerns are about negative impacts of industry on the quality of the subsurface environment. The discharge of industrial effluents leads to the infiltration of these pollutants into surface and groundwater, and subsequently, their contamination $(3,4)$. Uncontrolled discharge of industrial and agricultural wastewater and infiltration of municipal wastewater leads to groundwater contamination (5). Based on the quality of groundwater in different regions, and with proper management, the use of water resources for drinking or agricultural purposes can be allocated (1). The presence of HMs in surface and groundwater is usually related to human industrial activities. The vertical movement of these contaminants in soil profile can lead to groundwater contamination (6). Management of water resources and monitoring water quality are the ways to achieve sustainable development. Several factors including climate, soil properties, groundwater flow through a variety of rocks, area topography, infiltration of saline water into coastal areas, human activities on land, etc have a significant impact on water quality (7). The importance of water quality in the human health is one of the issues that have recently attracted more attention. A study by Olajire and Imeokparia shows that in the developing countries, a high percentage of diseases (over $80 \%$ ) are directly or indirectly related to the 
low quality of drinking water and unsanitary conditions (8). The study of groundwater quality has been focused by many researchers because hazardous substances such as HMs entering the groundwater, can enter the food chain, and ultimately, harm aquatic and human organisms (9). About $13 \%-30 \%$ of the total volume of freshwater in the hydrosphere is groundwater (10), which accounts for more than $50 \%$ of the world's population (11). The presence of HMs in the groundwater resources is a serious threat to public health. Because of the HMs biological stability and magnification, their contamination in aquatic environments has become a major global concern (12). Metals are naturally impermeable, intolerant, toxic, and biodegradable and can reside for thousands of years $(13,14)$. In terms of risk, these toxic elements are divided into two categories: carcinogenic and non-carcinogenic, which can be calculated in terms of health risk assessment (15). The health risk assessment is an effective and efficient way to evaluate the relationship between the environment and human health that can quantify the risk of HMs (16). Muhammad et al investigated the health risk of HMs in local populations as a result of contaminated water consumption, and found that the main causes of pollution were geogenic processes and anthropogenic activities in the Kohistan region (17).

Some HMs are considered as essential elements for plant growth, that are harmful to human health if their concentration exceeds the permissible level for drinking water (18-20). Therefore, the evaluation and control of HMs in groundwater, which are used for drinking purposes, is of great importance for human health.

Many studies have been carried out on the contamination of HMs in soils, plants, surface water, and groundwater due to human activities (21-24).

Marbooti et al investigated HMs contamination of groundwater in the Behbahan plain, Southwest Iran, as well as its suitability for drinking purposes. According to their results, the concentration of $\mathrm{Pb}, \mathrm{As}, \mathrm{Cd}$, and Se in this area was $33 \%, 13 \%, 56 \%$, and $100 \%$ higher than the permissible limit presented by the WHO, respectively (25). In another study, the chemical quality of groundwater of Bushehr, south of Iran, was assessed. The results of analysis of the concentration of HMs in this study showed that the quality of water in this area was not suitable for drinking purposes (26). Barzegar et al investigated the concentration of HMs, such as $\mathrm{Fe}, \mathrm{Cr}, \mathrm{Mn}, \mathrm{Al}$, and As in the Tabriz plain aquifer. Their results show the concentrations of studied heavy metals in some of the groundwater samples exceed the maximum admissible concentration (MAC). (27).

Accurate tracking and monitoring of pollutants and HMs in groundwater will help us better understand the status of water pollution in industrial areas. Therefore, there is a need for sustainable management to prevent water contamination, which requires detailed knowledge of groundwater chemistry.

The present study was conducted to quantify the HMs pollution of groundwater in Hamedan-Bahar plain (western Iran), affected by Bu-Ali industrial town, as well as its suitability for drinking purposes. The importance of this subject is highlighted because groundwater supplies approximately $88 \%$ of the water consumed in Hamadan. In Hamedan-Bahar plain, groundwater is the only available and widely used source of drinking water for rural and urban areas, as well as for irrigation (28).

For this purpose, the concentrations of 9 important HMs (arsenic, cadmium, chromium, copper, iron, lead, manganese, nickel, and zinc) were investigated in 26 groundwater samples. The samples were taken up to a 4 $\mathrm{km}$ radius around the industrial town. Pollution indicators and health assessments were investigated to find out the current status of groundwater contamination by the HMs.

\section{Materials and Methods}

Study area

The study zone was Hamedan-Bahar plain, western Iran, under the influence of Bu-Ali industrial town (Figure 1), which is located at longitude $48^{\circ} 34^{\prime} \mathrm{E}$ and latitude $34^{\circ} 56^{\prime} \mathrm{N}$. Hamedan-Bahar plain occupies about $880 \mathrm{~km}^{2}$, with a mean altitude of 1775 m.a.s.l. The study area is semi-arid, and the annual average precipitation is approximately 300 $\mathrm{mm}$, about $37 \%$ of which happens in winter. The annual potential evapotranspiration which exceeds the annual precipitation is about $1505 \mathrm{~mm}$.

In this area, groundwater is used for several purposes, like drinking, agricultural, domestic, and industrial purposes. Geologically, Hamadan-Bahar plain is located on Sanandaj-Sirjan metamorphic zone (Hamadan Regional Water Authority, HRWA). The parent rocks are generally composed of limestone, calcareous shale, and granitic materials. The soil texture in this area is silty loam on average with clay less than $17 \%$ (Information Center of Ministry of Jahade-Agriculture of Hamadan, MOJAH).

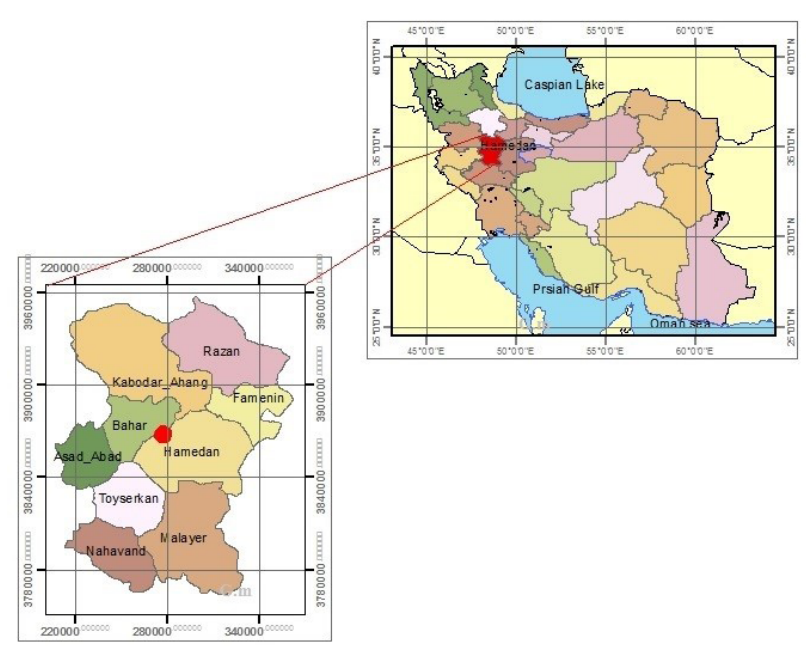

Figure 1. The location of Hamadan province in Iran indicated by the red point. 
Sampling and water analysis

Water samples were obtained from 26 wells during spring 2017 (Figure 2). For this purpose, a buffer zone with $4 \mathrm{~km}$ diameter was supposed around the industrial town. The samples were collected from the wells inside the selected area. The places of wells were recorded using a global positioning system (GPS).

Before sampling, all the sample containers were rinsed with distilled water. Samples were collected to assess the concentration of HMs and protected by $1 \%$ nitric acid $\left(\mathrm{HNO}_{3}\right)$. The containers were held in icebox at $4^{\circ} \mathrm{C}$ and carried to the laboratory for analysis.

Electrical conductivity (EC), total dissolved solids (TDS), and $\mathrm{pH}$ were analyzed using the Hach Series Meters (HQ40D) in place. The concentrations of the HMs (i.e., $\mathrm{As}, \mathrm{Cd}, \mathrm{Cr}, \mathrm{Cu}, \mathrm{Fe}, \mathrm{Pb}, \mathrm{Mn}, \mathrm{Ni}$, and $\mathrm{Zn}$ ) in groundwater samples were measured by inductively coupled plasmaoptical emission spectrometry (Varian E-710) in $\mu \mathrm{gL}^{-1}$, detection limit. That is linearly calibrated from 10 to $100 \mu \mathrm{gL}^{-1}$ with custom multi-element standards (SPEX CertiPrep, Inc., NJ, USA) before running the tests. The accuracy and precision of analyses were examined through running triplicate analysis on the samples. The comparative standard deviations for studied elements were found to be within $\pm 2 \%$.

Heavy metal evaluation index (HEI)

The HEI presents the overall quality of water based on the HMs concentrations $(29,30)$, and is expressed as Eq. (1):

$H(y)=\sum_{i=1}^{n} \frac{H_{c}}{H_{m a c}}$

where $H_{c}$ and $H_{\text {mac }}$ are the observed amount and MAC of the $i$ th parameter, respectively.

\section{Heavy metal pollution index (HPI)}

The HPI shows the quality of water in relation to the HMs concentrations $(31,32)$. The proposed HPI is based on the weighted arithmetic quality mean method and is obtained in two basic steps: First, a grading scale is created for each selected parameter rendering weightage to the selected parameter (HMs), and secondly, the pollution parameter on which the index is based, is selected. Grading system is either an arbitrary value between 0 and 1, depending on the importance of exclusive quality attentions in a comparative way or it can be distinguished by making values inversely proportional to the recommended standard for the responsible parameter $(33,34)$. In this equation, unit weightage $(\mathrm{Wi})$ is derived as a value inversely proportional to the recommended standard (Si) of the responsible parameter. The HPI model suggested by Mohan et al is expressed as Eq. (2) (34):

$H P I=\frac{\sum_{i=1}^{n} W_{i} Q_{i}}{\sum_{i=1}^{n} W_{i}}(2)$

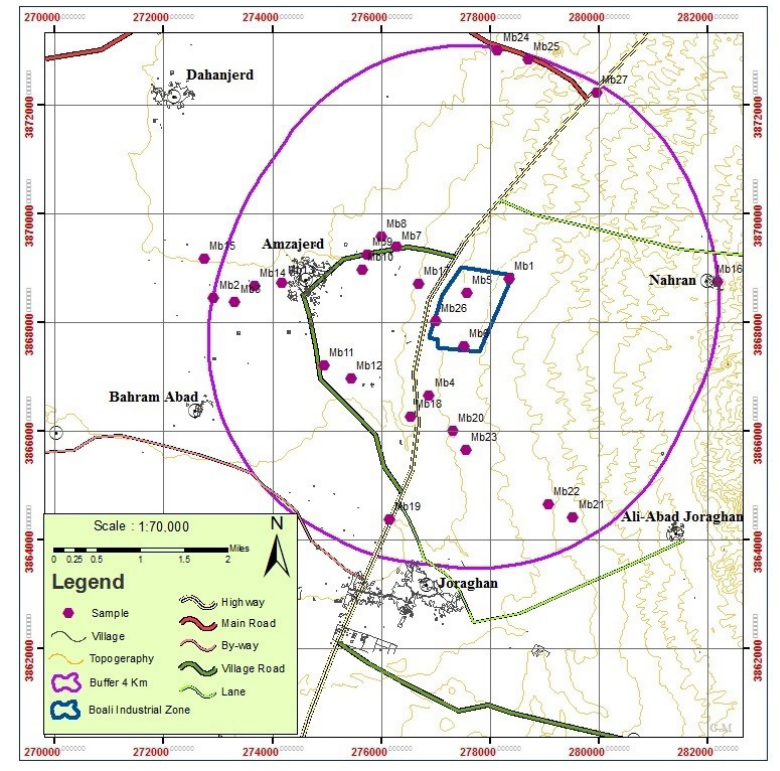

Figure 2. The location of water sampling points.

Where $Q i$ is the sub-index of the $i$ th parameter, $W i$ is the unit weightage of the $i$ th parameter, and $n$ is the number of parameters considered. The sub-index $(Q i)$ of the parameter is computed by Eq. (3):

$Q_{i}=\sum_{i=1}^{n} \frac{\left\{M_{i}(-) I_{i}\right\}}{\left(S_{i}-I_{i}\right)} \times 100(3)$

Where $M_{i}$ is the observed amount of HMs of the $i$ th parameter, $I_{i}$ is the perfection amount (the maximum favorable amount for drinking water) of the $i$ th parameter, and $S_{i}$ is the modulus value (the greatest allowed amount for drinking water) of the $i$ th parameter. The sign (-) demonstrates the numerical difference of the two values, relinquishing the algebraic mark. The critical pollution index of HPI value for drinking water suggested by Prasad and Bose, is 100 (35).

Degree of contamination (DOC)

The contamination index $\left(C_{d}\right)$ briefs the combined effects of various quality parameters considered adverse to homemade water (36) and is calculated using Eq. (4):

$$
\left(\mathcal{C}_{d}^{4}\right)=\sum_{i=1}^{n} C_{f i}
$$

where $C_{f i}=\left(C_{A i} / C_{N i}\right)-1, C_{f i}, C_{A i}$, and $C_{N i}$ represent the contamination factor, analytical value, and upper allowed concentration of the $i$ th component, respectively, and $N$ denotes the "normative value". Here, $C_{N i}$ is considered as MAC.

\section{Health risk assessment}

Basically, the assessment of the health risk of each contaminant is estimated based on its risk level and is classified into two groups: carcinogenic and non- 
carcinogenic health risks. In this study, the possible carcinogenic health risk of HMs present in groundwater was assessed using Eq. (5) (37):

\section{Health Risk $=A D D \times C S F(5)$}

where, $A D D$ is the average daily dose of HMs in water via oral exposure in the study area $\left(\mathrm{mg} \mathrm{kg}^{-1} \mathrm{day}^{-1}\right)$ and CSF is cancer slope factor. A CSF is an upper bound, approximating a $95 \%$ confidence limit, on the increased cancer risk from a lifetime exposure to toxicant by ingestion, dermal or inhalation exposure route (38). People who are living near contaminated areas may be at risk from drinking water sources or contact of the mouth with hands contaminated with such water. In this study, the average daily dose for each of the toxic metals (As, $\mathrm{Cd}, \mathrm{Cr}, \mathrm{Cu}, \mathrm{Fe}, \mathrm{Pb}, \mathrm{Mn}, \mathrm{Ni}$, and $\mathrm{Zn}$ ) ingested in the water bodies were calculated using Eq. (6) (37):

$A D D=\frac{E P C \times I R \times A A F_{W o} \times E F \times E D \times 10^{-6}}{B W \times A T}(6)$
The equation parameters are described in Table 1. The CSF values are presented in Table 2.

The acceptable health risk is one in million $\left(1 \times 10^{-6}\right)$, meaning that one person among one million people is likely to develop cancer due to drinking HMscontaminated groundwater (39).

\section{Results}

Minimum, maximum, and average concentrations of several water quality parameters in the groundwater samples are shown in Table 3. The $\mathrm{pH}$ of the samples ranged from 6.61 to 7.84 while the average $\mathrm{pH}$ was 7.28 (Table 3), which corresponds to the WHO standard for drinking water. EC ranged from 0.575 to $1.218 \mathrm{dS} \mathrm{m}^{-1}$. The Pearson's correlation (Table 4) indicates that EC had a strong correlation with TDS. The TDS quantities ranged from 291 to $827 \mathrm{mg} \mathrm{L}^{-1}$, while the average TDS level was 479.4. According to the WHO report, there is no health risk associated with drinking water with a TDS below $1000 \mathrm{mg} \mathrm{L}^{-1}(40)$.

The mean concentrations of $\mathrm{As}, \mathrm{Cd}, \mathrm{Cr}, \mathrm{Cu}, \mathrm{Fe}, \mathrm{Pb}, \mathrm{Mn}$,

Table 1. Parameters and input assumptions for exposure assessment of heavy metals through ingestion pathways

\begin{tabular}{llll}
\hline Parameter & Explanation & Unit & Value \\
\hline EPC & Exposure point concentration of a metal in the drinking water & $\mu \mathrm{g} \mathrm{L}^{-1}$ & - \\
$\mathrm{IR}$ & Water ingestion rate per unit time & $\mathrm{L} \mathrm{day}^{-1}$ & 2.2 \\
$\mathrm{AAF}_{\text {wo }}$ & Oral-water adjustment factor & $\mathrm{g} \mathrm{L}^{-1}$ & 0.001 \\
$\mathrm{EF}$ & Exposure frequency & Events year & 365 \\
ED & Exposure duration & Year & Kg \\
BW & Body weight & Day & 70 \\
AT & Averaging time & 70 \\
\hline
\end{tabular}

Table 2. Toxicity values (CSF)

\begin{tabular}{|c|c|c|c|c|c|c|c|c|c|}
\hline & As & $\mathrm{Cd}$ & $\mathrm{Cr}$ & $\mathrm{Cu}$ & $\mathrm{Fe}$ & $\mathrm{Mn}$ & $\mathrm{Ni}$ & pb & $\mathrm{Zn}$ \\
\hline $\operatorname{CSF}\left(\mathrm{mg} \mathrm{kg}^{-1} \mathrm{day}^{-1}\right)$ & 1.5 & 6.3 & 42 & - & - & - & 0.84 & 8.5 & - \\
\hline Ref & (7) & (7) & (7) & & & & (7) & (59) & \\
\hline
\end{tabular}

Table 3. Minimum, maximum, and average concentrations of some water quality parameters in the groundwater samples

\begin{tabular}{|c|c|c|c|c|}
\hline Water Quality Parameters & Units & Minimum Concentration & Maximum Concentration & Average \\
\hline $\mathrm{pH}$ & - & 6.61 & 7.84 & 7.28 \\
\hline EC & $\mathrm{dS} \mathrm{m}^{-1}$ & 0.575 & 1.218 & 0.949 \\
\hline TDS & $\mathrm{mg} \mathrm{L}^{-1}$ & 291.0 & 827.0 & 479.4 \\
\hline \multicolumn{5}{|l|}{ Heavy metal ions } \\
\hline As & $\mathrm{ppb}$ & 36.93 & 112.66 & 72.29 \\
\hline $\mathrm{Cd}$ & $\mathrm{ppb}$ & 18.31 & 34.50 & 25.91 \\
\hline $\mathrm{Cr}$ & $\mathrm{ppb}$ & 117.63 & 894.90 & 590.01 \\
\hline $\mathrm{Cu}$ & $\mathrm{ppb}$ & 138.16 & 650.23 & 461.19 \\
\hline $\mathrm{Fe}$ & $\mathrm{ppb}$ & 2829.63 & 7157.93 & 4965.04 \\
\hline $\mathrm{Pb}$ & $\mathrm{ppb}$ & 359.03 & 3580.96 & 2026.23 \\
\hline $\mathrm{Mn}$ & $\mathrm{ppb}$ & 120.93 & 409.42 & 269.08 \\
\hline $\mathrm{Ni}$ & $\mathrm{ppb}$ & 98.76 & 757.93 & 525.43 \\
\hline $\mathrm{Zn}$ & $\mathrm{ppb}$ & 173.50 & 1890.36 & 947.32 \\
\hline
\end{tabular}


Table 4. Correlation coefficient between heavy metal concentration $(\mathrm{ppb})$ and water quality parameters measured in the groundwater samples

\begin{tabular}{|c|c|c|c|c|c|c|c|c|c|c|c|c|}
\hline & $\mathrm{pH}$ & EC & TDS & As & $\mathrm{Cd}$ & $\mathrm{Cr}$ & $\mathrm{Cu}$ & $\mathrm{Fe}$ & $\mathrm{Pb}$ & $M n$ & $\mathrm{Ni}$ & $\mathrm{Zn}$ \\
\hline $\mathrm{pH}$ & 1.00 & & & & & & & & & & & \\
\hline EC & -0.11 & 1.00 & & & & & & & & & & \\
\hline TDS & -0.10 & $0.99^{* *}$ & 1.00 & & & & & & & & & \\
\hline As & -0.20 & 0.00 & -0.00 & 1.00 & & & & & & & & \\
\hline $\mathrm{Cd}$ & -0.13 & 0.06 & 0.07 & $0.49^{* *}$ & 1.00 & & & & & & & \\
\hline $\mathrm{Cr}$ & 0.13 & -0.08 & -0.12 & $0.76^{* *}$ & $0.47^{* *}$ & 1.00 & & & & & & \\
\hline $\mathrm{Cu}$ & 0.08 & -0.08 & -0.10 & $0.58^{* *}$ & $0.37^{* *}$ & $0.75^{* *}$ & 1.00 & & & & & \\
\hline $\mathrm{Fe}$ & 0.10 & -0.07 & -0.06 & $0.67^{* *}$ & $0.35^{* *}$ & $0.77^{* *}$ & $0.76^{* *}$ & 1.00 & & & & \\
\hline $\mathrm{Pb}$ & 0.03 & 0.01 & 0.04 & $0.70^{* *}$ & $0.36^{* *}$ & $0.67^{* *}$ & $0.49^{* *}$ & $0.53^{* *}$ & 1.00 & & & \\
\hline $\mathrm{Mn}$ & -0.07 & 0.02 & 0.14 & $0.63^{* *}$ & $0.63^{* *}$ & $0.65^{* *}$ & $0.49^{* *}$ & $0.62^{* *}$ & $0.58^{* *}$ & 1.00 & & \\
\hline $\mathrm{Ni}$ & -0.04 & 0.04 & 0.01 & $0.65^{* *}$ & $0.56^{* *}$ & $0.77^{* *}$ & $0.69^{* *}$ & $0.74^{* *}$ & $0.57^{* *}$ & $0.64^{* *}$ & 1.00 & \\
\hline $\mathrm{Zn}$ & 0.14 & -0.09 & -0.15 & $0.70^{* *}$ & $0.51^{* *}$ & $0.83^{* *}$ & $0.66^{* *}$ & $0.75^{* *}$ & $0.66^{* *}$ & $0.66^{* *}$ & $0.65^{* *}$ & 1.00 \\
\hline
\end{tabular}

${ }^{* *}$ Correlation is significant at $1 \%$ level of significance (two-tailed).

$\mathrm{Ni}$, and $\mathrm{Zn}$ were 72.29, 25.9, 590.0, 461.2, 4965.0, 2026.2, 269.0, 525.4, and $947.3 \mathrm{ppb}$, respectively, which contain total 26 groundwater sampling points. According to the WHO guideline for drinking water, the highest permissible concentrations for $\mathrm{As}, \mathrm{Cd}, \mathrm{Cr}, \mathrm{Cu}, \mathrm{Pb}$, and $\mathrm{Ni}$ are 10, 3, 50, 2000, and $70 \mathrm{ppb}$, respectively. For Fe, Mn, and Zn, a permissible limit concentration has not been established and none of health concern at levels found in drinking water for them. The concentrations of all studied HMs except $\mathrm{Cu}$, in groundwater exceed the permissible levels for drinking water, therefore, such water is not suitable for drinking (40).

In a similar study by Obiri et al, the concentration of As, $\mathrm{Cd}, \mathrm{Hg}$, and $\mathrm{Pb}$ in water samples of Prestea Huni Valley District of Ghana was investigated. They reported that the concentrations of all HMs were higher than the WHO recommended permissible values for drinking water (37). The results of analysis of groundwater resources in Behbahan plain southwest Zagros demonstrated that the concentrations of $\mathrm{Pb}, \mathrm{As}, \mathrm{Cd}$, and $\mathrm{Se}$ are 33, 13, 56, and $100 \%$ higher than the WHO recommended permissible levels, respectively (25).

Pollution indices

The quality of the groundwater samples was evaluated by measuring the concentration of the HMs in the samples (29). Figures 3-5 show the values of the HEI, HPI, and $\mathrm{C}_{\mathrm{d}}$ in the studied samples. The results of the calculations of HEI, HPI, and $\mathrm{C}_{\mathrm{d}}$ for one sample are demonstrated in Tables 5-7.

The HPI values ranged between 251.7 and 1202.1, with the average value of 815.5 , which exceeds the critical index value of 100 . The critical impurity index value over the overall pollution level should not be accepted (41). The HPI value was more than 100 , indicating that the groundwater is contaminated with metals due to all mineralization, mining, and industrial activities near the study area (20).

The value of DOC $\left(\mathrm{C}_{\mathrm{d}}\right)$ in the groundwater with an average value of 80.1 shows that the HMs concentrations in the groundwater samples were as follows: $\mathrm{Pb}>\mathrm{Ni}>\mathrm{Cr}>\mathrm{Fe}>$ $\mathrm{Cd}>\mathrm{As}>\mathrm{Cu}>\mathrm{Zn}>\mathrm{Mn}$.

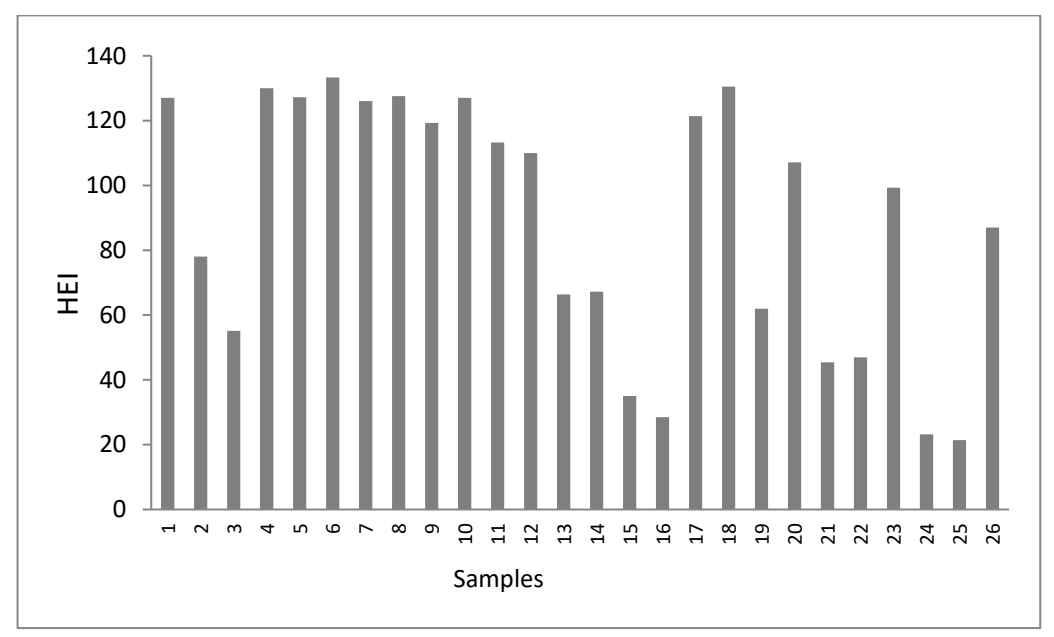

Figure 3. The HEI values for the studied groundwater samples. 


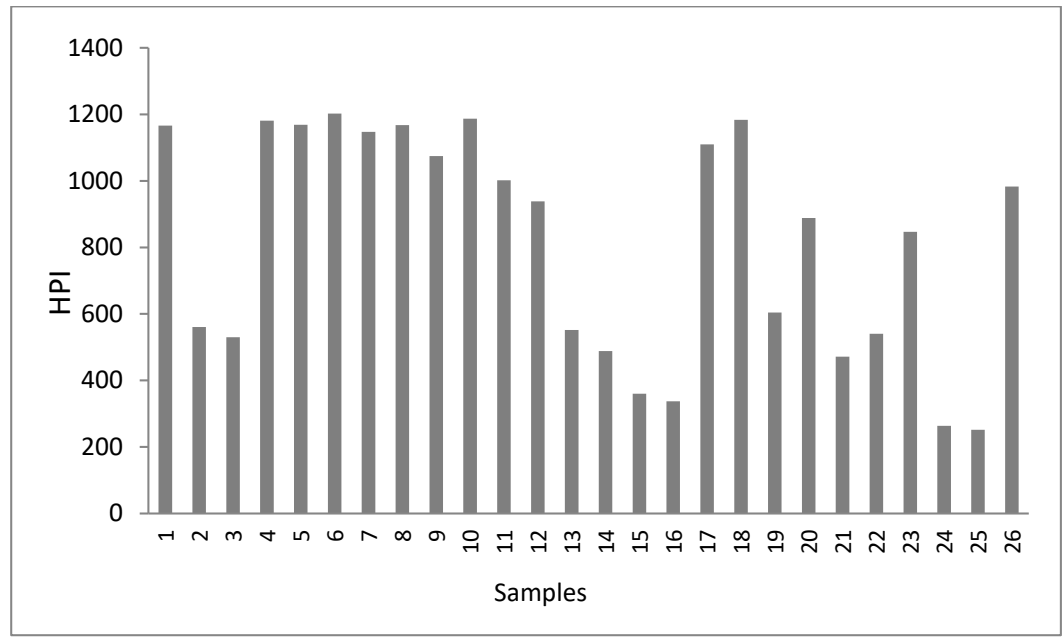

Figure 4. The HPI values for the studied groundwater samples.

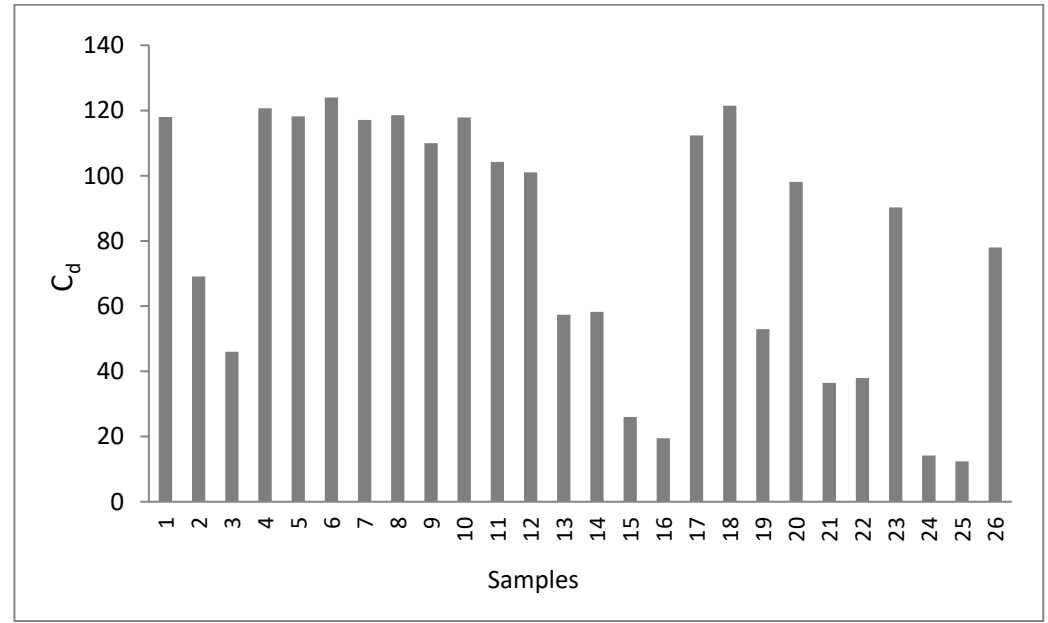

Figure 5. The $C_{d}$ values for the studied groundwater samples.

The average values of health risk of all studied HMs are described in Table 8. The health risks of As, Cd, Cr, Ni and $\mathrm{Pb}$ were all below the maximum acceptable level $\left(1 \times 10^{-6}\right)$, therefore, there is no health risk $(38,39)$.

\section{Discussion}

The optimum $\mathrm{pH}$ will change according to the composition of water and the nature of the ingredients in different water sources. According to the WHO guidelines for drinking water quality, it ranges usually between 6.5 and 8.5 (42). In accordance with the WHO guidelines, the quality of water with a TDS level less than about $600 \mathrm{mg} \mathrm{L}^{-1}$ is commonly supposed to be desirable, but drinking water becomes significantly and increasingly undesirable at TDS levels higher than about $1000 \mathrm{mg} \mathrm{L}^{-1}$ (42). TDS in groundwater are basically because of inorganic salts and dissolved organic matter. The salts may be of geogenic origin from rock weathering or anthropogenic source such as urban runoff, sewage, industrial depletion, kind of materials used for water supply piping etc (43).
The ability of metals to move in the soil is affected by several soil properties. According to Campos, the treatment of HMs in soil depends on $\mathrm{pH}$, texture, and amount of clay (44). Soil texture affects the amount of HMs as well as physicochemical properties and directly or indirectly controls the reactions occur on the surface of particles

Table 5. The results of HEl calculation for one of groundwater samples (example)

\begin{tabular}{lccc}
\hline Heavy Metals & $\boldsymbol{H}_{c}(\mathbf{p p b})$ & $\boldsymbol{H}_{\text {mac }}(\mathrm{ppb})$ & $\boldsymbol{H}_{\boldsymbol{c}} / \boldsymbol{H}_{\text {mac }}$ \\
\hline $\mathrm{As}$ & 112.7 & 50 & 2.2 \\
$\mathrm{Cd}$ & 27.6 & 10 & 2.8 \\
$\mathrm{Cr}$ & 809.9 & 50 & 16.2 \\
$\mathrm{Cu}$ & 590.4 & 1000 & 0.6 \\
$\mathrm{Fe}$ & 5272.7 & 1000 & 5.3 \\
$\mathrm{~Pb}$ & 3179.7 & 50 & 63.6 \\
$\mathrm{Mn}$ & 261.3 & 300 & 0.9 \\
$\mathrm{Ni}$ & 707.9 & 20 & 35.4 \\
$\mathrm{Zn}$ & 805.2 & 15000 & 0.04 \\
$\mathrm{HEI}$ & & & $\Sigma=127.04$ \\
\hline
\end{tabular}


Table 6. The results of HPI calculation for one of groundwater samples (example)

\begin{tabular}{|c|c|c|c|c|c|c|}
\hline Heavy Metals & $M_{i}(\mathrm{ppb})$ & $S_{i}(\mathrm{ppb})$ & $I_{i}(\mathrm{ppb})^{*}$ & $w_{i}$ & $Q_{i}$ & $W_{i} \times Q_{i}$ \\
\hline As & 112.7 & 50 & - & 0.02 & 225.4 & 4.9 \\
\hline $\mathrm{Cd}$ & 27.6 & 10 & - & 0.1 & 276.0 & 27.6 \\
\hline $\mathrm{Cr}$ & 809.9 & 50 & - & 0.02 & 1619.8 & 32.4 \\
\hline $\mathrm{Cu}$ & 590.4 & 1500 & 50 & 0.0007 & 37.3 & 0.03 \\
\hline $\mathrm{Fe}$ & 5272.7 & 1000 & 300 & 0.001 & 710.3 & 0.6 \\
\hline $\mathrm{Pb}$ & 3179.7 & 50 & - & 0.02 & 6359.4 & 127.2 \\
\hline $\mathrm{Mn}$ & 261.3 & 300 & 100 & 0.002 & 80.6 & 0.2 \\
\hline $\mathrm{Ni}$ & 707.9 & 70 & - & 0.009 & 1011.3 & 9.0 \\
\hline \multirow[t]{3}{*}{$\mathrm{Zn}$} & 805.2 & 15000 & 5000 & 0.00007 & 42.0 & 0.003 \\
\hline & & & & $\Sigma=0.16$ & & $\Sigma=202.0$ \\
\hline & & & & & & $\mathrm{HPI}=12625$ \\
\hline
\end{tabular}

*There are no desirable limits for $\mathrm{As}, \mathrm{Cd}, \mathrm{Cr}, \mathrm{Pb}$, and $\mathrm{Ni}$ according to the WHO guideline; hence, the optimal values were set equal to zero.

$(45,46)$. The $\mathrm{pH}$ of the soils in the studied area ranged between 6.8 and 7.2, which was rated slightly acidic and increases the mobility of HMs (47-49). Considering the soil texture and low percentage of clay in the soil samples of the studied area, it is revealed that the groundwater may be contaminated due to HMs movement. De Matos et al stated that the low levels of HMs in groundwater could be due to the presence of high percentage of clay in the soil, which have strong adsorptive sites for metals, and as a result, decrease their movement (47).

The mean concentrations of HMs in the groundwater samples were as follows: $\mathrm{Fe}>\mathrm{Pb}>\mathrm{Zn}>\mathrm{Cr}>\mathrm{Ni}>\mathrm{Cu}>\mathrm{Mn}$ $>$ As $>$ Cd. According to the results, the concentrations of $\mathrm{HMs}$ such as $\mathrm{Cu}, \mathrm{Mn}$, and $\mathrm{Zn}$ were well below the WHO recommended permissible levels for drinking water. The concentrations of $\mathrm{As}, \mathrm{Cd}, \mathrm{Cr}, \mathrm{Fe}, \mathrm{Pb}$, and $\mathrm{Ni}$ were higher than the WHO recommended value for drinking water (42).

Table 9 presents the concentration of HMs in groundwater reported by several researchers. It can be realized that the concentrations of HMs obtained in the present study are consistent with those represented by other researchers.

Table 7. The results of DOC $\left(C_{d}\right)$ calculation for one of groundwater samples (example)

\begin{tabular}{lccc}
\hline Heavy Metals & $\boldsymbol{C}_{A i}(\mathbf{p p b})$ & $\boldsymbol{C}_{\boldsymbol{N i}}(\mathbf{p p b})$ & $\boldsymbol{C}_{f i}$ \\
\hline $\mathrm{As}$ & 112.7 & 50 & 1.25 \\
$\mathrm{Cd}$ & 27.6 & 10 & 1.76 \\
$\mathrm{Cr}$ & 809.9 & 50 & 15.20 \\
$\mathrm{Cu}$ & 590.4 & 1000 & -0.41 \\
$\mathrm{Fe}$ & 5272.7 & 1000 & 4.27 \\
$\mathrm{~Pb}$ & 3179.7 & 50 & 62.59 \\
$\mathrm{Mn}$ & 261.3 & 300 & -0.13 \\
$\mathrm{Ni}$ & 707.9 & 20 & 34.40 \\
$\mathrm{Zn}$ & 805.2 & 15000 & -0.95 \\
$C_{d}$ & & & $\Sigma=117.99$ \\
\hline
\end{tabular}

The results of correlation analysis between HMs concentrations and $\mathrm{pH}, \mathrm{EC}$, and TDS in groundwater samples done to supplementary statistically prove for similar sources of pollution for samples. Pearson's correlation coefficients are presented in Table 4. The results demonstrated a strong correlation between HMs at $P<0.01$. This strong positive correlation between all studied HMs shows that they originate from the same source. Therefore, the accumulation of metals indicates that groundwater is more likely to be affected by the same sources, including chemical industry and municipal sewage or landfill leachate (54).

The HEI values ranged between 21.4 and 133.3, with the average value of 89.1. HEI examines the potential impact of HMs on human health leading to a rapid assessment of the overall quality of drinking water. Increasing the concentration of HMs higher than the MAC leads to a decrease in water quality. High HEI values can be caused by washing industrial waste from the soil as a result of anthropogenic activities (48). The proposed HEI criteria are as follows: Low $($ HEI $<10)$, medium $($ HEI $=10-20)$, and high $($ HEI $>20)$ (54). Based on the classification, the samples were within the high zone.

The $C_{d}$ values in the groundwater samples ranged from 12.4 to 124.0 , with a mean value of 80 . According to the results reported by Edet and Offiong and Backman et al, $C_{d}$ may be categorized into three classes: Low $\left(C_{d}<\right.$ $1)$, medium $\left(C_{d}=1-3\right)$, and high $\left(C_{d}>3\right)$. Based on the classification, all of the samples were within the high zone. The $C_{d}$ indices indicate that the samples were heavily polluted $(36,55)$.

The HPI was applied for better understanding of the pollution indices. It is a very helpful tool for evaluating the overall pollution of water considering HMs concentrations (41). Pollution of the HMs in the studied area could be due to leaching of these metals from the industries into the region. The HPI exceeded the critical metal pollution index of 100, which was suggested for drinking water by Prasad and Bose, knowing potentially hazardous effects 
Table 8. Mean HRI values for studied heavy metals in the groundwater samples

\begin{tabular}{lllllllll}
\hline As & Cd & Cr & Cu & Fe & Mn & $\frac{\mathrm{Nb}}{\mathrm{Zn}}$ \\
\hline Mean HRI & $3.4 \mathrm{E}-09$ & $5.1 \mathrm{E}-09$ & $7.8 \mathrm{E}-07$ & - & - & - & $\frac{\mathrm{Ni}}{5.4 \mathrm{E}-07}$ \\
\hline
\end{tabular}

Table 9. Heavy metals concentrations ( $\mathrm{ppb}$ ) in groundwater samples reported by other studies

\begin{tabular}{|c|c|c|c|c|c|c|c|c|c|}
\hline $\mathrm{Zn}$ & $\mathrm{Ni}$ & $M n$ & $\mathrm{~Pb}$ & $\mathrm{Fe}$ & $\mathrm{Cu}$ & As & $\mathrm{Cd}$ & $\mathrm{Cr}$ & Reference \\
\hline 39 & 315.6 & 23 & 63 & 42 & 51 & & 9 & 50.8 & (30) \\
\hline 1500.7 & 375.5 & & 116.4 & 10488 & 2151.8 & & 47.6 & 147.1 & (42) \\
\hline $0.24-45.2$ & & $8-264$ & $6-20$ & $12-500$ & $0.2-2.1$ & & $0.2-1.7$ & $0.5-11.8$ & (32) \\
\hline \multirow[t]{2}{*}{303.6} & & 60.6 & 52.6 & & 19.6 & 2 & 3.3 & 6 & (48) \\
\hline & & & 215 & & & 9 & 484 & & (25) \\
\hline 66 & - & 105 & 4 & 627 & 85 & - & 3 & - & (50) \\
\hline \multirow[t]{2}{*}{211.16} & & 166.2 & 3.8 & 541.6 & 8.4 & & 0.41 & 7.2 & (20) \\
\hline & & 95 & 40 & 1390 & & & 22 & 53 & (51) \\
\hline $120-980$ & $3.6-9.7$ & $130-340$ & $2.6-10$ & $3250-5080$ & $1.8-6.8$ & & & & $(52)$ \\
\hline $1-7380$ & & $10-522$ & $1-123$ & $280-5880$ & $1-272$ & & & & (53) \\
\hline $173.5-1890$ & $98.7-757.9$ & $120.9-409.4$ & 359-3580.9 & 2829.6-7158 & $138-650.2$ & $37-112.6$ & $18.3-34.5$ & $117.6-895$ & This study \\
\hline
\end{tabular}

on the aquatic environment (35). The HPI values in the studied groundwater show that the samples are not suitable for drinking (Figure 4).

Since the weightage $\left(W_{i}\right)$ assigned to $\mathrm{Cu}$ and $\mathrm{Zn}$ was very less in the weighing of the parameters (Table 4), it can be concluded that the concentration of these metals would not have a significant effect on the HPI assessment. On the other hand, $\mathrm{As}, \mathrm{Cd}, \mathrm{Cr}$, and $\mathrm{Pb}$ were not allowed in drinking water, therefore, they were given high weightage $\left(W_{i}\right)$ value in the HPI computation. Hence, the presence of a small amount of these elements in water reduces water quality and depicts great values in the HPI computation. The problems related to heavy metal pollution are among the most important issues in environmental science. Daily consumption of drinking water containing these metals threat human health and can cause various types of cancer (56). The health risk associated with drinking water depends on the volume of water consumed and the weight of the individual. In this regard, health risk assessment associated with the average daily dose (ADD) was determined using the concentrations of $\mathrm{As}, \mathrm{Cd}, \mathrm{Cr}$, $\mathrm{Cu}, \mathrm{Fe}, \mathrm{Pb}, \mathrm{Mn}, \mathrm{Ni}$, and $\mathrm{Zn}$ in the water used for drinking. Heavy metals (As, $\mathrm{Cd}, \mathrm{Cr}, \mathrm{Pb}$, and $\mathrm{Ni}$ ) can potentially pose a risk of cancer in humans $(57,58)$. Therefore, prolonged exposure to HMs can lead to many types of cancers. For an HM, an ILCR less than $1 \times 10^{-6}$ is considered as insignificant and the cancer risk can be neglected, while an ILCR above $1 \times 10^{-4}$ is considered as harmful and the cancer risk is troublesome $(57,59)$. Among studied $\mathrm{HMs}, \mathrm{As}, \mathrm{Cd}, \mathrm{Cr}, \mathrm{Ni}$, and $\mathrm{Pb}$ had no cancer risk (mean HRI lower than $\left.1 \times 10^{-6}\right)$. Since $\mathrm{Cu}, \mathrm{Fe}, \mathrm{Mn}$, and $\mathrm{Zn}$ are essential elements for human beings and abundant in nature, there is no health concern about drinking water containing these elements. Thus, the results of this study indicate that there is no cancer risk for residents through daily and long-term consumption of drinking water of the groundwater.

Mohammadi et al assessed carcinogenic and noncarcinogenic health risk of HMs in drinking water of Khorramabad, Iran, and concluded that the health risk for $\mathrm{Pb}, \mathrm{Cr}, \mathrm{Cd}$, and $\mathrm{Ni}$ was higher than the permissible limit $\left(1 \times 10^{-6}\right)(58)$. Wongsasuluk et al also evaluated the HMs pollution in groundwater in Ubon Ratchathani province, Thailand, and reported that only the concentration of As was within the unacceptable cancer risk level (60). Kim et al accessed the health risk of uranium in Korean groundwater, and demonstrated that radiological risk was within acceptable ranges (61). In Nanjing, China, a study on six surface waters showed the carcinogenic value of $2.05-3.28 \times 10^{-4}$, which was higher than the acceptable limit (62).

\section{Conclusion}

The results of the present study showed that the HMs concentrations in most samples are generally higher than the permissible limits for drinking water, according to the WHO guideline. Among the HMs verified in the present study, the sequence of the mean concentrations of HMs was recorded to be as $\mathrm{Pb}>\mathrm{Ni}>\mathrm{Cr}>\mathrm{Fe}>\mathrm{Cd}>\mathrm{As}>\mathrm{Cu}>$ $\mathrm{Zn}>\mathrm{Mn}$, considering the $C_{d}$ index.

The correlation analysis demonstrated good to strong positive correlations among all HMs, proposing that the HMs have the same origin and it can be attributed to the associated industries along with the neighbor wells. In the present study, the mean HPI of groundwater was 815.5 , which is higher than the critical index value of 100 , indicating that the groundwater in this area is contaminated with HMs. Similarly, the mean HEI value 
of the groundwater samples was 89.1. Also, the results of evaluation of the health risk index indicate that there is no cancer risk for residents through daily and long-term consumption of such groundwater.

The results of the present study clearly illustrated that the contamination of groundwater with HMs was mainly due to industrial and anthropogenic activities.

Eventually, the study of soil and geological characteristics of the region and accurate identification and introduction of pollution sources are important goals that can be followed in future studies.

\section{Acknowledgements}

The authors would like to gratitude all those who contributed in the project.

\section{Ethical issues}

The authors hereby certify that all data collected during the research are as expressed in the manuscript, and no data from the study has been or will be published elsewhere separately.

\section{Competing interests}

The authors declare that they have no conflict of interests.

\section{Authors' contributions}

All authors contributed to data collection, analysis, and interpretation. All authors reviewed, refined, and approved the manuscript.

\section{References}

1. Asadi E, Isazadeh M, Samadianfard S, Ramli MF, Mosavi A, Nabipour N, et al. Groundwater quality assessment for sustainable drinking and irrigation. Sustainability 2020; 12(1): 177. doi: 10.3390/su12010177

2. Amiri V, Rezaei M, Sohrabi N. Groundwater quality assessment using entropy weighted water quality index (EWQI) in Lenjanat, Iran. Environ Earth Sci 2014; 72(9): 3479-90. doi: 10.1007/s12665-014-3255-0.

3. Jameel AA, Sirajudeen J. Risk assessment of physicochemical contaminants in groundwater of Pettavaithalai area, Tiruchirappalli, Tamilnadu - India. Environ Monit Assess 2006; 123(1-3): 299-312. doi: 10.1007/s10661-0069198-5.

4. Marghade DT, Malpe DB, Zade AB. Geochemical characterization of groundwater from northeastern part of Nagpur urban, Central India. Environ Earth Sci 2011; 62(7): 1419-30. doi: 10.1007/s12665-010-0627-y.

5. Dechesne M, Barraud S, Bardin JP. Indicators for hydraulic and pollution retention assessment of stormwater infiltration basins. J Environ Manage 2004; 71(4): 371-80. doi: $\quad$ 10.1016/j.jenvman.2004.04.005.

6. Moolenaar SW, Van der Zee SE, Lexmond TM. Indicators of the sustainability of heavy-metal management in agroecosystems. Sci Total Environ 1997; 201(2): 155-69. doi: 10.1016/s0048-9697(97)00123-x.

7. Agarwal A, Mangal A, Satsangi A, Lakhani A, Maharaj Kumari K. Characterization, sources and health risk analysis of PM2.5 bound metals during foggy and nonfoggy days in sub-urban atmosphere of Agra. Atmos Res 2017; 197: 121-31. doi: 10.1016/j.atmosres.2017.06.027.

8. Olajire AA, Imeokparia FE. Water quality assessment of Osun river: studies on inorganic nutrients. Environ Monit Assess 2001; 69(1): 17-28. doi: 10.1023/a:1010796410829.

9. Nouri J, Mahvi AH, Jahed GR, Babaei AA. Regional distribution pattern of groundwater heavy metals resulting from agricultural activities. Environ Geol 2008; 55(6): 1337-43. doi: 10.1007/s00254-007-1081-3.

10. Dragoni W, Sukhija BS. Climate change and groundwater: a short review. Geol Soc London Spec Publ 2008(1); 288: 1-12. doi: 10.1144/sp288.1.

11. Hofmann J, Watson V, Scharaw B. Groundwater quality under stress: contaminants in the Kharaa River basin (Mongolia). Environ Earth Sci 2015; 73(2): 629-48. doi: 10.1007/s12665-014-3148-2.

12. Islam MS, Ahmed MK, Raknuzzaman M, Habibullah-AlMamun M, Islam MK. Heavy metal pollution in surface water and sediment: A preliminary assessment of an urban river in a developing country. Ecol Indic 2015; 48: 282-91. doi: $10.1016 /$ j.ecolind.2014.08.016.

13. Adriano DC. Trace Elements in Terrestrial Environments: Biogeochemistry, Bioavailability and Risks of Metals. New York: Springer; 2001.

14. Pekey H, Karakaş D, Bakoğlu M. Source apportionment of trace metals in surface waters of a polluted stream using multivariate statistical analyses. Mar Pollut Bull 2004; 49(910): 809-18. doi: 10.1016/j.marpolbul.2004.06.029.

15. US Environmental Protection Agency (EPA). National Primary/Secondary and Drinking Water Regulations. Washington, DC: EPA; 2009.

16. Ma Y, Egodawatta P, McGree J, Liu A, Goonetilleke A. Human health risk assessment of heavy metals in urban stormwater. Sci Total Environ 2016; 557-558: 764-72. doi: 10.1016/j.scitotenv.2016.03.067.

17. Muhammad S, Shah MT, Khan S. Health risk assessment of heavy metals and their source apportionment in drinking water of Kohistan region, northern Pakistan. Microchem J 2011; 98(2): 334-43. doi: 10.1016/j.microc.2011.03.003.

18. Chanpiwat P, Sthiannopkao S, Kim KW. Metal content variation in wastewater and biosludge from Bangkok's central wastewater treatment plants. Microchem J 2010; 95(2): 326-32. doi: 10.1016/j.microc.2010.01.013.

19. Muhammad S, Shah MT, Khan S. Arsenic health risk assessment in drinking water and source apportionment using multivariate statistical techniques in Kohistan region, northern Pakistan. Food Chem Toxicol 2010; 48(10): 285564. doi: 10.1016/j.fct.2010.07.018.

20. Prasad B, Kumari P, Bano S, Kumari S. Ground water quality evaluation near mining area and development of heavy metal pollution index. Appl Water Sci 2014; 4(1): 117. doi: 10.1007/s13201-013-0126-x.

21. Kedziorek MA, Etchebers O, Reynal-Preud'homme C, Bourg AC. Natural attenuation of heavy metals (Cd, Cr, and $\mathrm{Pb}$ ) in a water table aquifer underlying an industrial site. Procedia Earth Planet Sci 2013; 7: 89-92. doi: 10.1016/j. proeps.2013.03.114.

22. Abdel-Satar AM, Al-Khabbas MH, Alahmad WR, Yousef WM, Alsomadi RH, Iqbal T. Quality assessment of 
groundwater and agricultural soil in Hail region, Saudi Arabia. Egypt J Aquat Res 2017; 43(1): 55-64. doi: 10.1016/j. ejar.2016.12.004.

23. Galitskaya IV, Mohan KR, Krishna AK, Batrak GI, Eremina ON, Putilina VS, et al. Assessment of soil and groundwater contamination by heavy metals and metalloids in Russian and Indian megacities. Procedia Earth Planet Sci 2017; 17: 674-7. doi: 10.1016/j.proeps.2016.12.180.

24. Tirkey P, Bhattacharya T, Chakraborty S, Baraik S. Assessment of groundwater quality and associated health risks: a case study of Ranchi city, Jharkhand, India. Groundw Sustain Dev 2017; 5: 85-100. doi: 10.1016/j.gsd.2017.05.002.

25. Marbooti Z, Khavari R, Ehya F. Heavy metal contamination assessment of groundwater resources in Behbahan Plain Southwest Zagros. Open J Geol 2015; 5(5): 325-30. doi: 10.4236/ojg.2015.55029.

26. Sarikhani R, Ghassemi Dehnavi A, Ahmadnejad Z, Kalantari N. Hydrochemical characteristics and groundwater quality assessment in Bushehr province, SW Iran. Environ Earth Sci 2015; 74(7): 6265-81. doi: 10.1007/s12665-015-4651-9.

27. Barzegar R, Asghari Moghaddam A, Kazemian N. Assessment of heavy metals concentrations with emphasis on arsenic in the Tabriz plain aquifers, Iran. Environ Earth Sci 2015; 74(1): 297-313. doi: 10.1007/s12665-015-4123-2.

28. Akhavan S, Abedi-Koupai J, Mousavi SF, Afyuni M, Eslamian SS, Abbaspour KC. Application of SWAT model to investigate nitrate leaching in Hamadan-Bahar Watershed, Iran. Agric Ecosyst Environ 2010; 139(4): 67588. doi: 10.1016/j.agee.2010.10.015.

29. Edet AE, Offiong OE. Evaluation of water quality pollution indices for heavy metal contamination monitoring. A study case from Akpabuyo-Odukpani area, Lower Cross River Basin (southeastern Nigeria). GeoJournal 2002; 57(4): 295304. doi: 10.1023/B:GEJO.0000007250.92458.de.

30. Selvam S, Venkatramanan S, Singaraja C. A GIS-based assessment of water quality pollution indices for heavy metal contamination in Tuticorin Corporation, Tamilnadu, India. Arab J Geosci 2015; 8(12): 10611-23. doi: 10.1007/ s12517-015-1968-3.

31. Tiwari AK, De Maio M, Singh PK, Mahato MK. Evaluation of surface water quality by using GIS and a heavy metal pollution index (HPI) model in a coal mining area, India. Bull Environ Contam Toxicol 2015; 95(3): 304-10. doi: 10.1007/s00128-015-1558-9.

32. Singh G, Kamal RK. Heavy metal contamination and its indexing approach for groundwater of Goa mining region, India. Appl Water Sci 2017; 7(3): 1479-85. doi: 10.1007/ s13201-016-0430-3.

33. Horton RK. 1965. An index number system for rating water quality. J Water Pollut Control Fed 1965; 37(3): 300-6.

34. Mohan SV, Nithila P, Reddy SJ. Estimation of heavy metals in drinking water and development of heavy metal pollution index. J Environ Sci Health A 1996; 31(2): 283-9. doi: $10.1080 / 10934529609376357$.

35. Prasad B, Bose J. Evaluation of the heavy metal pollution index for surface and spring water near a limestone mining area of the lower Himalayas. Environ Geol 2001; 41(1): 1838. doi: 10.1007/s002540100380.

36. Backman B, Bodiš D, Lahermo P, Rapant S, Tarvainen T. Application of a groundwater contamination index in
Finland and Slovakia. Environ Geol 1998; 36(1): 55-64. doi: 10.1007/s002540050320.

37. Obiri S, Yeboah PO, Osae S, Adu-Kumi S, Cobbina SJ, Armah FA, et al. Human health risk assessment of artisanal miners exposed to toxic chemicals in water and sediments in the Prestea Huni Valley District of Ghana. Int J Environ Res Public Health 2016; 13(1): 139. doi: 10.3390/ ijerph13010139.

38. Environmental Protection Agency (EPA). Exposure Factors Handbook.Washington, DC: EPA; 2011.

39. Gebeyehu HR, Bayissa LD. Levels of heavy metals in soil and vegetables and associated health risks in Mojo area, Ethiopia. PLoS One 2020; 15(1): e0227883. doi: 10.1371/ journal.pone. 0227883 .

40. World Health Organization, World Bank. World Report on Disability. Geneva: WHO; 2011.

41. Prasad B, Sangita K. Heavy metal pollution index of ground water of an abandoned open cast mine filled with fly ash: a case study. Mine Water Environ 2008; 27(4): 265-7. doi: 10.1007/s10230-008-0050-8.

42. World Health Organization. Guidelines for drinking-water quality. 4th ed. Geneva: WHO; 2017.

43. Bhardwaj R, Gupta A, Garg JK. Evaluation of heavy metal contamination using environmetrics and indexing approach for River Yamuna, Delhi stretch, India. Water Sci 2017; 31(1): 52-66. doi: 10.1016/j.wsj.2017.02.002.

44. Campos MC. Atributos dos solos e riscos de lixiviação de metais pesados em solos tropicais, Soil attributes and risk of leaching of heavy metals in tropical soils. Ambiência 2010; 6(3): 547-65.

45. He Z, Li J, Zhang H, Ma M. Different effects of calcium and lanthanum on the expression of phytochelatin synthase gene and cadmium absorption in Lactuca sativa. Plant Sci 2005; 168(2): 309-18. doi: 10.1016/j.plantsci.2004.07.001.

46. Salman SA, Zeid SA, Seleem EM, Abdel-Hafiz MA. Soil characterization and heavy metal pollution assessment in Orabi farms, El Obour, Egypt. Bull Natl Res Cent 2019; 43(1): 42. doi: 10.1186/s42269-019-0082-1.

47. de Matos AT, Fontes MP, da Costa LM, Martinez MA. Mobility of heavy metals as related to soil chemical and mineralogical characteristics of Brazilian soils. Environ Pollut 2001; 111(3): 429-35. doi: 10.1016/s02697491(00)00088-9.

48. Balakrishnan A, Ramu A. Evaluation of heavy metal pollution index (HPI) of ground water in and around the coastal area of Gulf of Mannar Biosphere and Palk Strait. J Adv Chem Sci 2016; 22: 331-3.

49. Krol A, Mizerna K, Bozym M. an assesment of $\mathrm{pH}$ dependent release and mobility of heavy metals from metallurgical slag. J Hazard Mater 2020; 384: 121502. doi: 10.1016/j.jhazmat.2019

50. Musa OK, Shaibu MM, Kudamnya EA. Heavy metal concentration in groundwater around obajana and its environs, kogi state, north central Nigeria. American International Journal of Contemporary Research 2013; 3(8): $170-77$.

51. Amin S, Farjoud Mr, Shabani A. Groundwater contamination by heavy metals in water resources of Shiraz area. Iran Agric Res 2012; 30(1-2): 21-32. doi: 10.22099/ iar.2012.491. 
52. Giri S, Singh G, Gupta SK, Jha VN, Tripathi RM. An evaluation of metal contamination in surface and groundwater around a proposed uranium mining site, Jharkhand, India. Mine Water Environ 2010; 29(3): 225-34. doi: 10.1007/s10230-010-0107-3.

53. Chetia M, Singh SK, Bora K, Kalita H, Saikia LB, Goawami DC, et al. Groundwater arsenic contamination in three blocks of Golaghat district of Assam. Journal of Indian Water Works Association 2008; 40(2): 150-4.

54. Boateng TK, Opoku F, Acquaah SO, Akoto O. Pollution evaluation, sources and risk assessment of heavy metals in hand-dug wells from Ejisu-Juaben Municipality, Ghana. Environ Syst Res 2015; 4(1): 18. doi: 10.1186/s40068-0150045-y.

55. Sobhanardakani S. Evaluation the water quality pollution indices for groundwater resources of Ghahavand plain, Hamedan province, western Iran. Iranian Journal of Toxicology 2016; 10(3): 35-40. doi: 10.29252/ arakmu.10.3.35.

56. Yu FC, Fang GH, Ru XW. Eutrophication, health risk assessment and spatial analysis of water quality in Gucheng Lake, China. Environ Earth Sci 2010; 59(8): 1741-8. doi: 10.1007/s12665-009-0156-8.

57. Cao S, Duan X, Zhao X, Ma J, Dong T, Huang N, et al. Health risks from the exposure of children to $\mathrm{As}, \mathrm{Se}, \mathrm{Pb}$ and other heavy metals near the largest coking plant in
China. Sci Total Environ 2014; 472: 1001-9. doi: 10.1016/j. scitotenv.2013.11.124.

58. Mohammadi AA, Zarei A, Majidi S, Ghaderpoury A, Hashempour Y, Saghi MH, et al. Carcinogenic and noncarcinogenic health risk assessment of heavy metals in drinking water of Khorramabad, Iran. MethodsX 2019; 6: 1642-51. doi: 10.1016/j.mex.2019.07.017.

59. Yang G, Li Y, Wu L, Xie L, Wu J. Concentration and health risk of heavy metals in topsoil of paddy field of Chengdu Plain. Environ Chem 2014; 33: 269-75.

60. Wongsasuluk P, Chotpantarat S, Siriwong W, Robson M. Heavy metal contamination and human health risk assessment in drinking water from shallow groundwater wells in an agricultural area in Ubon Ratchathani province, Thailand. Environ Geochem Health 2014; 36(1): 169-82. doi: 10.1007/s10653-013-9537-8.

61. Kim YS, Park HS, Kim JY, Park SK, Cho BW, Sung IH, et al. Health risk assessment for uranium in Korean groundwater. J Environ Radioact 2004; 77(1): 77-85. doi: 10.1016/j. jenvrad.2004.03.001.

62. Wu B, Zhao DY, Jia HY, Zhang Y, Zhang XX, Cheng SP. Preliminary risk assessment of trace metal pollution in surface water from Yangtze River in Nanjing Section, China. Bull Environ Contam Toxicol 2009; 82(4): 405-9. doi: $\quad 10.1007 / \mathrm{s} 00128-008-9497-3$. 